\title{
巻機山(上越地方)の山頂付近に生育するグラミノイド代表種の 種子発芽とその地表面温度
}

\section{角谷文代 ${ }^{*} 1 ＼mathrm{~ ： 桑 山 直 子 ~ 2 ） － 鈴 木 貢 次 郎 ~ 3) ~}$}

1）東京農業大学農学研究科造園学専攻卒

2) JA アグリげんきの郷

3）東京農業大学地域環境科学部

\begin{abstract}
摘要 : 新潟県と群馬県境に位置する巻機山の山頂付近は, 登山道 を中心に植生が破壊されてきた。植生が破壊された場所の踏み込 み防止後には, ヌマガヤやヒロハノコメススキ, ヤチカワズスゲ 等のグラミノイドが多く生育することで知られている。これら 3 種の種子発芽温度条件や種子が散布される現地の地表面温度を 測定し, 巻機山山頂付近の踏み込み防止後の場所にグラミノイド が多くなる理由を考察した。

キーワード : 植生復元, グラミノイド, 地表面温度
\end{abstract}

\section{1. はじめに}

巻機山(標高 $1,967 \mathrm{~m}$ の魚沼連峰新潟県立自然公園, 及び 群馬県立自然環境保全地域)には, 山頂一帯に点在する池塘や オオシラビソの針葉樹林等, 優美な景観がある。昭和 40 年 代 (1965 年頃)の第一次登山ブーム時に植生破壊が起き, 1977 年から現在に至るまで播種や植付け等による植生復元 活動が行われてきた。これまでの高山での植生復元工では, 種子が効率よく多量に採種できるヌマガヤ (Moliniopsis japonica (Hack.) Hayata) やヒロハノコメススキ (Deschampsia caespitosa(L.) Beauv. var. festucaefolia Honda), ヤチカワズスゲ(Carex omiana Franch.etSavat.) が多く用いられてきたが、計画通りの発芽・生長が営まれな い事例も時にみられた ${ }^{4)}$ 。

中でも, 約 20 年間にわたり毎年行われた植生復元工後の 追跡調査によれば，踏み込みを防止すると約 7 年をかけてわ ずかのタテヤマリンドウやイワショウブ, キンコウカ等が, ショウジョウスゲやヌマガヤ，ヒロハノコメススキ等のグラ ミノイド(イネ科もしくはこれに類似した植物)に混じって生 育していることがわかった 5 )。

そこで本研究では，高山の山頂付近に生育するグラミノイ ドの代表種の種子発芽温度条件と現地の地表面温度との関係 を調べ, 高山の踏み込みを防止した後にグラミノイドが多く なる理由を考察した。

\section{2. 材料および方法}

\section{1 種子発芽試験の材料}

巻機山山頂付近 (図-1 の標高 1,825〜1,960 m) で相当する グラミノイドの種としてはヌマガヤ，ショウジョウスゲ (Carex blepharicarpa Franch.)，ヒロハノコメススキ，ヤチ カワズスゲ, ミヤマイヌノハナヒゲ (Rhynchospora yasudana Makino)であった 5)。このうち, 現地においてヌ マガヤ, ヒロハノコメススキ, ヤチカワズスゲから種子を採 取できたため，これを種子発芽試験に用いた。

\section{2 種子発芽試験}

種子発芽に及ぼす温度条件を調べる一方, 種子を採取して からの期間(種子齢)や種子がおかれる温度，水分条件と発芽

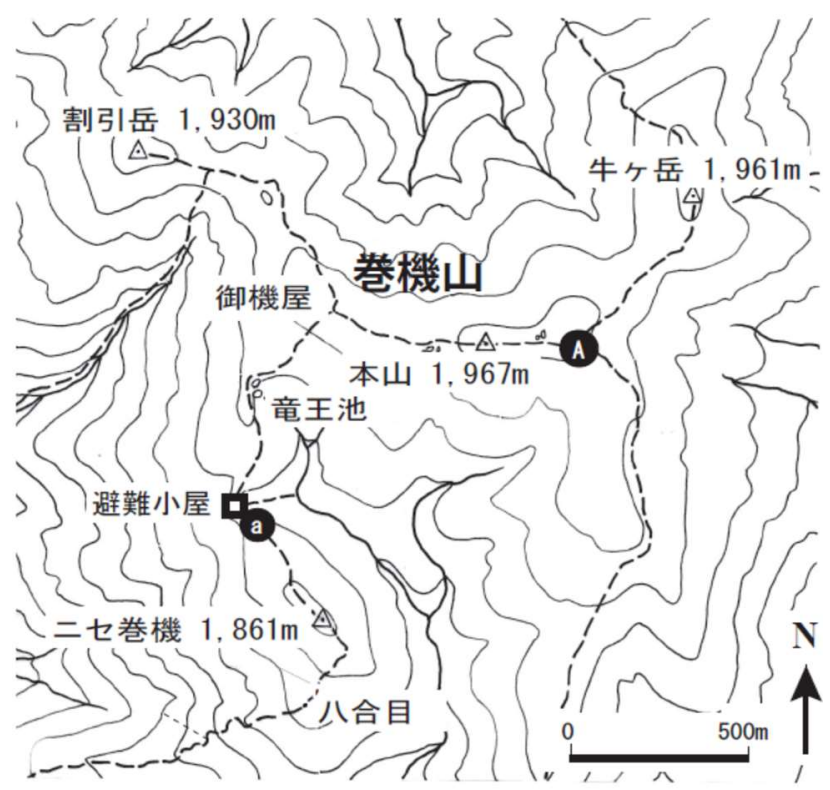

図-1＼cjkstart地表面温度の測定地(新潟県巻機山)

等高線は $50 \mathrm{~m}$ 間隔 $($ は温度計の設置場所 $\mathrm{A}$ :裸地区, $\mathrm{a}$ :植生区)

*連絡先著者（Corresponding author）：干156-8502 東京都世田谷区桜丘 1-1-1 E-mail : fumiy0cha@yahoo.co.jp 
率との関係について調べた。まず $10 \sim 30{ }^{\circ} \mathrm{C}$ までの $5{ }^{\circ} \mathrm{C}$ 間隔 に設定した恒温器室内で採取直後の種子発芽に及ぼす温度条 件を調べた。対象植物の種子は秋に結実するため, 散布後の 種子が積雪下におかれることを想定し，残った種子材料を低 温湿潤処理した(ろ紙を敷き水道水を浸したシャーレに種子 を置床し $5{ }^{\circ} \mathrm{C}$ の恒温器に置く, 表-1)。採種後から又マガヤは 3 ケ月間, ヒロ八ノコメススキは 2 ケ間低温湿潤処理した。 ヤチカワズスゲは $5{ }^{\circ} \mathrm{C}$ 冷蔵庫に 6,9 ケ月，または 1 年間紙 袋に入れて約 $5{ }^{\circ} \mathrm{C} に$ 貯蔵した (乾燥貯蔵)ものを 1.5 ケ月間, 低温湿潤処理し発芽率を求めた。予備試験で供試した種子材 料はいずれも明条件(蛍光灯で 1 日当り 2 時間照射)の方が暗 条件(全く光を照射しない)よりも発芽率が高くなったため, 発芽床は水道水に浸した 2 枚重祆のろ紙を敷いた径 $9 \mathrm{~cm} の$ ガラスシャーレを用いた。 1 シャーレ当たり 50 粒の種子を置 床した。恒温器は蛍光灯 $(28.7 \mu \mathrm{mol}-2 \cdot \mathrm{S}-1)$ を 12 時間照射し た日本医科器械製作所製温度勾配器 TG-200-ADCT を用い た。発芽試験を始めるまで果皮(種皮)を付けたままにし，発 芽試験の際に果皮(種皮)を全て除去した。

発芽数は 1 週間に 1 度の頻度で発芽を終えるまで数え, 発 芽曲線で示した。ヒロハノコメススキのみ 1 反復の実験で行

表-1 実験に供試した種子材料と発芽試験方法

\begin{tabular}{|c|c|c|c|}
\hline 植物名 & 採種日 & $\begin{array}{c}\text { 種子発芽試験の実施方法 } \\
\text { (時期, 実験年月日) }\end{array}$ & $\begin{array}{l}\text { 種子発芽試 } \\
\text { 験床の } \\
\text { 温度 }\left({ }^{\circ} \mathrm{C}\right)\end{array}$ \\
\hline \multirow[t]{2}{*}{ ヌマガヤ } & \multirow{2}{*}{$\begin{array}{l}\text { 2003年 } \\
\text { 9月 } 23 \text { 日 }\end{array}$} & 1. 採種直後 (2003年10月 8日) & \multirow{2}{*}{$\begin{array}{ll}10, & 15,20 \\
25, & 30\end{array}$} \\
\hline & & $\begin{array}{c}\text { 2. 低温湿潤貯蔵 (3 ケ月間, } \\
\text { 2004年1月 } 8 \text { 日) }\end{array}$ & \\
\hline \multirow{2}{*}{$\begin{array}{l}\text { ヒロハノ } \\
\text { コメスス } \\
\text { キ }\end{array}$} & \multirow{2}{*}{$\begin{array}{l}\text { 2002年 } \\
\text { 9月 } 15 \text { 日 }\end{array}$} & 1. 採種直後 (2002年9月 17 日) & \multirow{2}{*}{$\begin{array}{ll}10, & 15,20 \\
25, & 30\end{array}$} \\
\hline & & $\begin{array}{l}\text { 2. 低温湿潤貯蔵 (2 ケ月間, } \\
2002 \text { 年 } 11 \text { 月 } 17 \text { 日) }\end{array}$ & \\
\hline \multirow[t]{6}{*}{$\begin{array}{l}\text { ヤチカワ } \\
\text { ズスゲ }\end{array}$} & \multirow[t]{6}{*}{$\begin{array}{l}2002 \text { 年 } \\
9 \text { 月 } 15 \text { 日 }\end{array}$} & $\begin{array}{l}\text { 1. 低温乾燥貯蔵 }(6 \text { ケ月間, } \\
2003 \text { 年 } 3 \text { 月 } 7 \text { 日) }\end{array}$ & $\begin{array}{ll}10, & 15,20, \\
25, & 30\end{array}$ \\
\hline & & $\begin{array}{c}1 \text {. 低温乾燥 }(6 \text { ケ月間 })+ \\
\text { 低温湿潤貯蔵 }(1.5 \text { ケ月 } \\
\text { 間) }, 2003 \text { 年 } 4 \text { 月 } 22 \text { 日 } \\
\end{array}$ & $15,20,25$ \\
\hline & & $\begin{array}{l}\text { 2. 低温乾燥貯蔵 }(9 \text { ケ月間, } \\
2003 \text { 年 } 6 \text { 月 } 7 \text { 日) }\end{array}$ & $\begin{array}{l}10,15,20 \\
25,30\end{array}$ \\
\hline & & $\begin{array}{l}2^{\prime} . \text { 低温乾燥貯蔵 }(9 \text { ケ月間 })+ \\
\text { 低温湿潤貯蔵 }(1 \text { ケ月間 }), \\
2003 \text { 年 } 7 \text { 月 } 7 \text { 日 } \\
\end{array}$ & $15,20,25$ \\
\hline & & $\begin{array}{c}3 . \text { 低温乾燥貯蔵 (1 年間, } \\
2003 \text { 年 } 9 \text { 月 } 7 \text { 日) }\end{array}$ & $\begin{array}{l}10,15,20 \\
25,30\end{array}$ \\
\hline & & $\begin{array}{l}\text { 3'. 低温乾燥貯蔵 }(1 \text { 年間 })+ \\
\text { 低温湿潤貯蔵 }(2 \text { ケ月間 }), \\
2003 \text { 年 } 11 \text { 月 } 7 \text { 日 }\end{array}$ & $15,20,25$ \\
\hline
\end{tabular}

い，その他のヌマガヤとヤチカワズスゲは， 3 反復の平均值 で発芽率を求めた。

\section{3 地表面温度の測定}

上述のヌマガヤ，ヒロハノコメススキ，中チカワズスゲが 多く生育している巻機山山頂付近 (八合目 1,808〜 $1,852 \mathrm{~m}$, 図-1) で地表面温度を調べた。発芽実験に供試したグラミノ イドは，植生復元地あるいは基盤の露出が進み，碩の移動の 激しい場所の路傍に多い。そのため, 裸地区で植生がなく表 土が流出している地表面温度を測定した。またグラミノイド が育っている植生の中でも多くの種子発芽や生長が予測され るため, ヌマガヤ等のグラミノイドが育つ植生区内の地表面 温度も測定した。

測定は 2004 年 6 月 1 日〜同年 11 月 15 日の間に行った。 温度計は図- 1 に示すように巻機山山頂付近の “避難小屋” と “本山” 近くの 2 地点に設置した。本山付近に裸地区 (A 区, 標高 $1960 \mathrm{~m}$, 平坦地), 避難小屋付近に植生区 ( $\mathrm{a}$ 区: 標高 $1825 \mathrm{~m}$, 傾斜度 $16^{\circ}$, 傾斜方位東北東, 植被率 $75 \%$, 土袞 の粘性は強，埴土）を設けた。

温度計は自記温度記録計 (AES Laboratoire 社製, Temperature logger Tomprobe，直径約 $1 \mathrm{~cm}$ ，厚さ約 $5 \mathrm{~mm}$ の円盤状)を用い, 測定は 1 時間/回の記録とした。いずれも 長さ約 $20 \mathrm{~cm}$ の杭を地面に挿し, それに温度計を針金で留め て固定した。結果は日内の最高・最低温度の平均值を求めた。

\section{3. 結果}

\section{1 グラミノイド 3 種の種子発芽特性}

ヌマガヤ，ヒロ八ノコメススキの採取直後の種子，および 低温乾燥条件下に 6 ケ月間貯蔵したヤチカワズスゲの種子 は，いずれも $10 \sim 30{ }^{\circ} \mathrm{Cで} 10 \%$ 以下の発芽率であった。しか し低温湿潤処理をヌマガヤ: 3 ケ月間, ヒロ八ノコメススキ: 2 ケ月間，ヤチカワズスゲ： 1.5 ケ月間行った後，10〜 $30{ }^{\circ} \mathrm{C} に$ おくと, 最高でヌマガヤ: 約 $90 \%$ (図-2), ヒロハノコメスス キ: $100 \%$ (図-3), ヤチカワズスゲ: $65 \%$ (図-4)の発芽率を示 し，しかも 1 3 週間でその多くの発芽を終えた。

低温湿潤処理した種子材料の温度別の発芽率をみると, 又

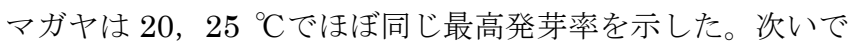
$30{ }^{\circ} \mathrm{C}, 15{ }^{\circ} \mathrm{C}$ と続き $10{ }^{\circ} \mathrm{C}$ での発芽率は最も低くなった(図 -2)。同じく低温湿潤処理したヒロ八ノコメススキの種子の最 終発芽率は $25{ }^{\circ} \mathrm{C}$ で $100 \%, 20{ }^{\circ} \mathrm{C}$ と $15{ }^{\circ} \mathrm{C}$ で約 $90 \%, 30{ }^{\circ} \mathrm{C}$ で $70 \%$ とり $10{ }^{\circ} \mathrm{Cでは} 60 \%$ となった(図-3)。

ヤチカワズスゲは 6 ケ月間乾燥貯蔵した後， 1.5 ケ月間低

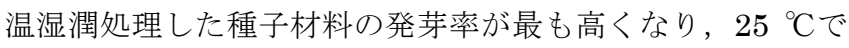
約 $65 \%, 20{ }^{\circ} \mathrm{C}$ で $45 \%, 15{ }^{\circ} \mathrm{C}$ で $20 \%$ の最高発芽率を示した。 9 ヶ月間または 1 年間乾燥貯蔵し, その後 1.5 ヶ月間低温湿 潤処理した種子材料の発芽率は，次第に低くなった。

以上によりヌマガヤ，ヒロ八ノコメススキ，ヤチカワズス ゲの種子は 1 ケ月半〜 3 ケ月間の低温湿潤処理を行うと比較 的高い温度 $\left(20 \sim 25{ }^{\circ} \mathrm{C}\right)$ で高発芽率を示すことがわかった。 


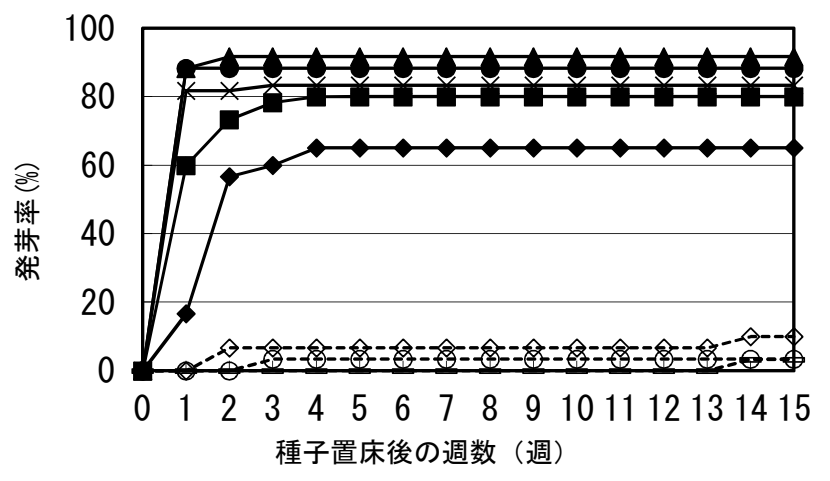

図-2 ヌマガヤの種子発芽曲線

$\diamond, \diamond: 10{ }^{\circ} \mathrm{C} ; \mathbf{\square}: 15{ }^{\circ} \mathrm{C} ; \boldsymbol{\Delta}: 20{ }^{\circ} \mathrm{C} ; \bigcirc, \bigcirc: 25{ }^{\circ} \mathrm{C}$;

$\times,-$ : $30{ }^{\circ} \mathrm{C}$. 破線白塗り: 採種直後, 実線黒: 低温湿潤 処理後。採種直後の $15{ }^{\circ} \mathrm{C}$ と $20{ }^{\circ} \mathrm{C}$ では発芽なし

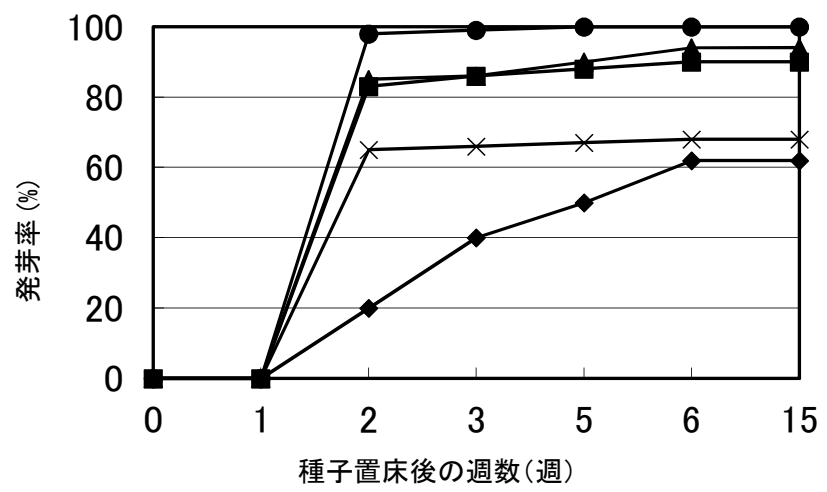

図-3 ヒロハノコメススキの種子発芽曲線

•: $10{ }^{\circ} \mathrm{C}, \boldsymbol{\square}: 15{ }^{\circ} \mathrm{C}, \boldsymbol{\Delta}: 20{ }^{\circ} \mathrm{C}, \quad \mathbf{0}: 25{ }^{\circ} \mathrm{C}, \quad \times: 30{ }^{\circ} \mathrm{C}$ 採種直後は全温度条件で発芽なし

\section{2 地表面温度}

2004 年 6 ～11 月にかけて巻機山山頂付近の植生区と裸地 区で測定した地表面温度のうち，6,7,10月の結果を図-5に示 す。日内の最低温度の差は, 調査時期や調査区に関わらず, ほとんどみられなかった。雪融け後 (6 月)の地表面の日内最 高温度は $25{ }^{\circ} \mathrm{C}$ 以上 (時には $30 \sim 40{ }^{\circ} \mathrm{C}$ )になり, 7 月は裸地 区と植生区のいずれも上旬 $\left(9\right.$ 日)までは $30{ }^{\circ} \mathrm{C}$ 超えること も多く, 特に植生区では最高で $58{ }^{\circ} \mathrm{C}$ 達することがあった。 下旬 (23 日頃) から再び高くなり，植生区では時に $50{ }^{\circ} \mathrm{C} に$ 達 し, 下旬 (24 日頃) までは植生区が裸地区よりも高くなる傾向 を示した。しかし 9 月下旬 $(25$ 日)〜 11 月 12 日までは，植生 区よりも裸地区の地表面温度の方が高くなることが多かっ た。その地表面温度は $25{ }^{\circ} \mathrm{C}$ 達することもあったが， 11 月 15 日には低下し，0 ${ }^{\circ} \mathrm{C}$ なった。11月 13 日以降は積雪と思 われる要因により, 最高温度と最低温度の差がみられず $0{ }^{\circ} \mathrm{C}$ を示した。なお 2005 年の 3 月〜8 26 日まで測定した地表 面温度によれば 5 月 21 日までの地表面温度は $0{ }^{\circ} \mathrm{Cだった。}$
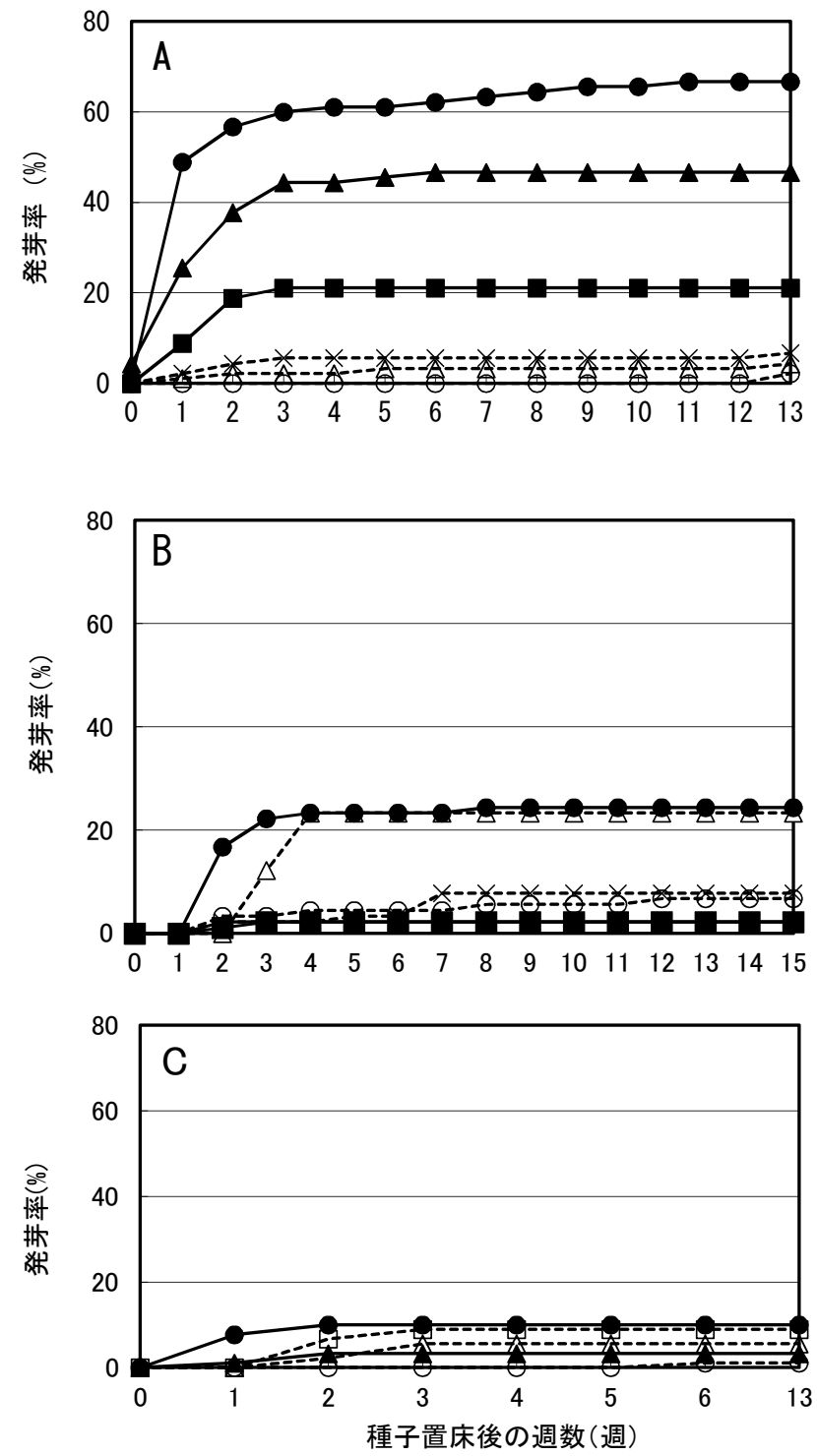

図-4 ヤチカワズスゲの種子発芽曲線

種子採取後から乾燥貯蔵した期間; A 6 ケ月間 (2003 年 3 月 7 日まで), B: 9 ケ月間 (2003 年 6 月 7 日まで), C:1 年間 (2003 年 9 月 7 日まで)。実線と黒塗り：乾燥貯蔵後 1.5 ケ月間の低温湿潤処理，破線と白塗り：無処理(乾燥 貯蔵)。 $\diamond: 10{ }^{\circ} \mathrm{C}, \square, \square: 15{ }^{\circ} \mathrm{C}, \boldsymbol{\Delta}, \triangle: 20{ }^{\circ} \mathrm{C}, \bigcirc, \bigcirc$ :25 ${ }^{\circ} \mathrm{C}, \times: 30{ }^{\circ} \mathrm{C}$ 。いずれも低温湿潤処理後の $10{ }^{\circ} \mathrm{C}$ と $30{ }^{\circ} \mathrm{C}$ での種子発芽試験は未実施。 $\mathrm{A}$ と B：乾燥貯蔵後の $10{ }^{\circ} \mathrm{C}$ と $15{ }^{\circ} \mathrm{C}$ では発芽なし。C:乾燥貯蔵後の $10{ }^{\circ} \mathrm{C}$ と $30{ }^{\circ} \mathrm{C}$, 低温湿潤処理の $15{ }^{\circ} \mathrm{C}$ では発芽なし

\section{4. 考察}

本実験の結果，ヌマガヤ，ヒロハノコメススキ，ヤチカワ ズスゲの種子は比較的高い温度 (約 $25{ }^{\circ} \mathrm{C}$ ) で発芽した。この ような傾向は巻機山山頂付近に多く生育するゼンテイカ 

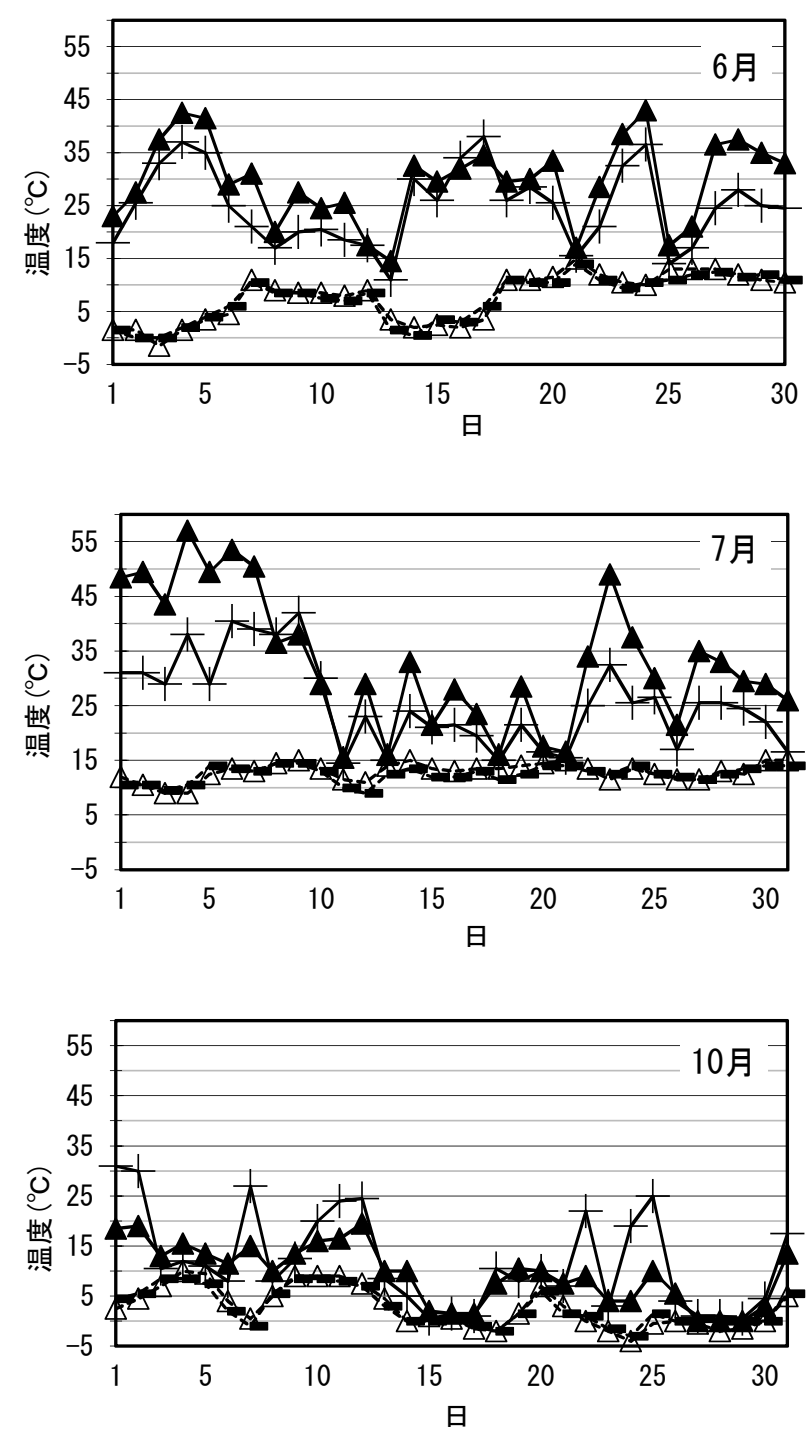

図-5 裸地区と植生区の地表面温度(2004 年 6,7,10月の結果)

$\boldsymbol{\Delta}$ と $\triangle$ : 裸地区 $(\mathrm{A}) ;$ + と - : 植生区 $(\mathrm{a}) ; \boldsymbol{\Delta}$ と + :日内最高 気温, $\triangle$ と一: 日内最低気温

(Hemerocallis dumortieri Morr.esculenta(Koidz.) Kitam) でもみられた 9)。また Baskin and Baskin11によれば，亜高山 帯の樹木種子は高温で発芽する傾向があるという。林 2)によ ると標高 $1,750 〜 1,800 \mathrm{~m}$ に多いシラカンバや, $1,900 〜 2,100$ $\mathrm{m}$ に多いダケカンバの種子は， $30{ }^{\circ} \mathrm{C}$ で最高発芽率を示した という。さらに標高 $1,750 \sim 1,800 \mathrm{~m}$ に多く生育するシラカ ンバの種子は $20{ }^{\circ} \mathrm{C}$ で $23 \%$ の発芽を示す一方, 標高 1,900 $2,100 \mathrm{~m}$ に多く生育するダケカンバの種子は $20{ }^{\circ} \mathrm{C}$ 以下で発 芽しないという。小水内3)によれば, ダケカンバとシラカン バの種子は低温 $\left(0 \sim 5{ }^{\circ} \mathrm{C}\right.$ に 20 日間置いた $)$ 処理をした後, 5 〜 $15{ }^{\circ} \mathrm{C}$ りも 20〜 $30{ }^{\circ} \mathrm{C}$ で高発芽率を示したという。また 長野県茅野市蓼科高原の海抜 $1,500 \mathrm{~m}$ 付近で採種したイタド

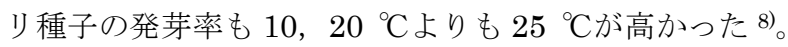

一方, 雪融け後 (6月, 発芽期) の巻機山山頂付近(標高 $1,900 \mathrm{~m}$ 内外)の地表面温度は $25{ }^{\circ} \mathrm{C}$ 以上 (時に $30 \sim 40{ }^{\circ} \mathrm{C}$ )になった。 北海道大雪山の標高約 $2,100 \mathrm{~m}$ の尾根付近の地表面温度は 6 月下旬及び 7 月上・中旬に $40{ }^{\circ} \mathrm{C}$ 以上，時に最高 $45{ }^{\circ} \mathrm{C}$ に達 したという6)。一般に高山では気温が低いという印象が先行 し，地表面の温度も低いと思われる。しかし，これらの報告 から, 晴天時の山岳地における地表面の温度は高温になる時 もあると考えられる。

桑山ほか 5)による「裸地の植生復元工によりヌマガヤ, ヒ ロハノコメススキが多くなった」こと，また中村 7)による「露 出が進み, 砅の移動の激しい場所ではグラミノイドが多い」

原因としてヌマガヤ，ヒロハノコメススキの種子が比較的高 い温度 $\left(25{ }^{\circ} \mathrm{C}\right)$ で発芽することと, 雪解け後の地表面温度が

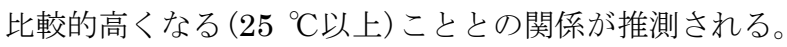

また裸地の場合, 乾燥状態になることが多い。ヌマガヤ, ヒロハノコメススキの種子は乾果 (頴果)であり, 外・内花頴 に包まれ高温や乾燥から保護されると考えられる。逆に, 同 じ現地に多く生育するゼンテイカの種子は，乾燥により発芽

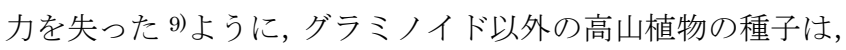
乾燥条件下では発芽力を失うものが多いと考えられる。

以上の結果，高山における植生復元工では，山岳地に生育 する多くの植物の種子は比較的高い温度で多く発芽するこ と, また山岳地の地表面温度が夏季に高温になったり, 乾燥 したりすることに留意する必要があると思われる。

\section{引用文献}

1) Baskin,C.C.andBaskin,M,J.(2014)Seed.pp.506-835,Acad emic Press, Elsevier. CA.USA.

2) 林一六 (2003)植物生態学基礎と応用. 古今書院, 227pp.

3）小水内正明(1972)ダケカンバ・シラカンバの発芽に関する 一実験. 日本生態学会誌, 22:19-23.

4）栗田和弥・麻生恵（1995）多雪山岳地における雪田植生の 復元方法に関する研究. 日本緑化工学会誌, 20: 223-333.

5）桑山直子 · 鈴木貢次郎 - 麻生恵 - 根本正之 (2004)巻機山(上 越地方)における植生復元工後の植生動態. 東京農業大学農 学集報, 43:105-112.

6) 宮本昌幸・武田泉(2006)大雪山小泉岳の雪田における気温 および地表面・積雪表面温度の観測. 北海道教育大学大雪 山自然教育研究施設研究報告, 40:41-52.

7）中村幸人(1986)中部山岳以西の亜高山性植生および高山性 植生の植物社会学的研究 I 群落区分とその体系化. 横浜国 立大学環境科学研究センター紀要, 13:151-206.

8）柴田治・新井澄(1970)異なった高度で生育したイタドリの 種子発芽. 日本生態学会誌, 20:9-13.

9) Suzuki,K.,Nakajima,A.andHamano,C.(2004)Coldinduce dgerminationpromotion in Hemerocallis dumortieri var. esculenta and H. fulva var. littorea seeds.In: The Biology of seeds: recent research advances (eds.Nicolas,G.,Bradford,K.J.andPritchard,H.W)pp.405412,CABI, Wallingford.

(2017 年 6 月 18 日受理) 